\title{
'DIVA THE SERIES' SEBAGAI MEDIA PEMBELAJARAN UNTUK MENANAMKAN NILAI SOSIAL DAN KEAGAMAAN BAGI ANAK
}

\author{
Suciati \\ STAIN Kudus, Jawa Tengah, Indonesia \\ suci@stainkudus.ac.id
}

\begin{abstract}
This article aimed to know the social values and religious values found in cartoon movie "Diva the Series" and know the effect of cartoon movie "Diva the Series" on the children's development. In analyzing data, the writer used qualitative method which focused on content analysis with research subjects "Diva the Series" episode 1-50. The analysis result showed that social values found in that movie involve economic value, recreation values, association values, body values and character values where the character and association values dominate in this social values. Religious values found in cartoon movie "Diva the Series" involve faith values, observance values, and moral characters. And the third result showed that cartoon movie "Diva the Series" has positive effect on the children's development because it has high social and religious values so they can be more sensitive or responsive to whatever condition.
\end{abstract}

Keywords: "Diva The Series", Teaching Media, Social Values, Religious Values. 


\section{Abstrak}

Artikel ini bertujuan untuk mengetabui nilai sosial dan nilai keagamaan yang ada dalam film kartun 'Diva the Series' serta mengetahui bagaimana pengarub film kartun "Diva the Series" terhadap perkembangan anak. Subjek penelitian ini adalab film kartun "Diva the Series". Dalam menganalisis data, penulis menggunakan metode penelitian kualitatif yang fokus pada content analysis (analisis isi) dengan subjek penelitian "Diva the Series" episode 1-50 . Dari hasil analisis menunjukkan bahwa nilai sosial yang terkandung dalam film tersebut adalah nilai ekonomi, nilai rekreasi, nilai perserikatan, nilai kejasmanian dan nilai watak dengan nilai watakdan perserikatan mendominasi dalam nilai sosial ini. Nilai keagamaan yang terkandung dalam film kartun "Diva the Series" meliputi nilai keimanan, nilai ibadah dan nilai akblak. Dan hasil ketiga menunjukkah babwa film kartun "Diva the Series" memiliki pengaruh positif terbadap perkembangan anak. karena mengandung nilai sosial dan keagamaan yang sangat tinggi sehingga anak menjadi lebib peka terbadap kondisi apapun.

Kata kunci: "Diva The Series", Media Pembelajaran, Nilai Sosial, Nilai Keagamaan.

\section{A. Pendahuluan}

Perkembangan teknologi dan informasi yang semakin pesat tentunya memberikan efek besar kepada anak. Pola pikir mereka sedikit banyak akan terpengaruh oleh apa yang ada di sekitar mereka. Rasa penasaran dan keinginan untuk selalu mencoba yang baru biasanya selalu mengimbangi perkembangan yang ada, khususnya perkembangan teknologi dan informasi. Berbagai macam bentuk sajian teknologi informasi dapat dinikmati anak-anak kapanpun dan dimanapun. Untuk itu, sajian positif harusnya diberikan oleh orang tua kepada anak.

Sajian atau program yang ada di televisi saat ini sangat minim dengan kepedulian akan karakter dan perkembangan anak. Pada era 90-an, banyak sekali program lagu anak-anak yang 
menghiasi televisi di nusantara ini. Anak-anak dapat menikmati lirik lagu yang sesuai dengan perkembangan dan lingkungan mereka, yaitu masa dan lingkungan anak-anak. Hal ini sangat jauh berbeda dengan apa yang ada saat ini. Televisi sering menjadi ancaman bagi perkembangan anak karena minimnya acara untuk anak-anak dan di sisi lain, banyak sekali program yang tidak sesuai dengan perkembangan anak dan itu disajikan pada waktu atau jam-jam anak istirahat. Banyak sekali program anak yang mengandung unsur kekerasan dan program-program remaja yang mengisahkan tentang cinta ataupun pergaulan bebas. Programprogram ini banyak diminati oleh anak-anak karena minimnya program acara anak atau kurang cocoknya waktu tayang.

Dalam kondisi kritis seperti ini, peran dan perhatian orang tua sangat diperlukan. Pendidikan moral harus menjadi prioritas. Pendidikan yang tepat harus diberikan karena hal ini akan membantu terbentuknya sikap dan kepribadian anak. Apa yang dilihat akan sangat mempengaruhi sikap mereka karena usia anak-anak adalah tahapan meniru. Apa yang mereka lihat akan menjadi referensi bagaimana mereka bersikap atau berinteraksi dengan teman-teman atau lingkungan mereka. Kita tahu bahwa manusia belajar mengenai langkah-langkah sosial dari apa yang mereka lihat atau yang mereka alami melalui interaksi sosial. Untuk itu, program-program televisi harus secara selektif dipilih oleh orang tua untuk anak-anaknya sehingga anak-anak memperoleh acuan atau referensi dalam bertingkah laku dalam berinteraksi dengan teman yang lain. Dengan demikian, anak-anak akan dapat diterima dalam lingkungan yang ada. Nilai sosial positif dari anak atau masyarakat akan membentuk kehidupan yang harmonis dan demokratis karena nilai tersebut memiliki posisi tinggi dalam kehidupan bermasyarakat, berbangsa dan bernegara. ${ }^{1}$

Sesuai dengan latar belakang diatas, maka penulis berusaha untuk melakukan analisis nilai-nilai sosial dan keagamaan yang

${ }^{1}$ Zubaidi, Pendidikan Berbasis Masyarakat, (Yogyakarta: Pustaka Pelajar, 2006), hlm. 13 
terdapat dalam film kartun "Diva the Series". Agar analisis jelas, maka penulis merumuskan beberapa tujuan, yaitu (1) menjelaskan nilai-nilai sosial yang ada dalam film kartun "Diva the Series"; (2) menjelaskan nilai-nilai keagamaan yang ada dalam film kartun "Diva the Series"; dan (3) menjelaskan bagaimana pengaruh film kartun "Diva the Series" terhadap perkembangan anak.

Dalam penelitian ini, penulis menggunakan metode penelitian kualitatif dengan analisis data kualitatif, yaitu menganalisis nilai sosial dan nilai keagamaan yang terkandung dalam film kartun 'Diva the Series'. Adapun subjek penelitian ini adalah 50 episode "Diva the Series" yang diproduksi oleh Kastari Animation dan biasanya ditayangkan di RTV.

Analysis is process of resolving data into its constituent component to reveal its characteristic elements and structure. ${ }^{2}$ Dari definisi lan Dey tersebut dapat diketahui bahwa analisis merupakan proses pemecahan data menjadi komponen-komponen yang lebih kecil berdasarkan elemen dan struktur tertentu. Sedangkan, menurut Bogdan dan Biglen dalam Moleong, analisis data kualitatif adalah upaya yang dilakukan dengan jalan bekerja dengan data, mengorganisasikan data, memilah-milahnya menjadi satuan yang dapat diolah, mensintesiskan, mencari dan menemukan pola, menemukan apa yang penting dan apa yang dipelajari dan memutuskan apa yang dapat diceritakan kepada orang lain. ${ }^{3}$ Kemudian, Seiddel dalam Burhan Bungin menjelaskan bahwa analisisi data kualitatif memiliki beberapa proses, yaitu:

1. Proses mencatat apa yang ada di lapangan atau data yang diperlukan

2. Proses mengumpulkan data, memilah dan mengkalisifikasikan, menyintesiskan, dan membuat rangkuman

\footnotetext{
${ }^{2}$ Ian Dey, Qualitative Data Analysis, (New York: RNY, 1995), hlm. 30

${ }^{3}$ Lexy J. Moleong, Metodologi Penelitian Kualitatif, (Bandung: PT. Remaja Rosdakarya, 2009), hlm. 248
} 
3. Proses mengkategorikan data, yaitu dengan mencari dan menemukan pola atau hubungan

4. Proses perumusan temuan.

Dari beberapa pengertian di atas, dapat diketahui bahwa analisis data kualitatif adalah cara mengungkap makna dari data yang diteliti dengan cara mengumpulkan dan mengklasifikasikan apa yang menjadi tujuan atau target dari penelitian ini. Dan dalam penelitian ini, analisis data dilakukan penulis dengan cara induktif, yaitu peneliti menganalisis data yang ada, yaitu film 'Diva the Series'. Kemudian, penulis menyimpulkan hasilnya sesuai dengan pertanyaan yang ada di rumusan masalah, khususnya nilai-nilai sosial dan keagamaan yang ada di dalamnya. Dari hasil kesimpulan tersebut, maka menjadi hasil penelitian.

Dalam tahapan kategorisasi data, penulis melakukan beberapa tahapan, yaitu reduksi data, penyajian atau display data dan kesimpulan atau verifikasi. Tahapan pertama yaitu reduksi data. Mereduksi data adalah proses merangkum, memilah mana yang penting dan tidak serta fokus pada yang menjadi tujuan penelitian atau analisis data. ${ }^{4}$ Dapat juga dikatakan bahwa proses ini dilakukan dengan cara membuat catatan-catatan dari analisis data.

Dengan demikian, dapat dipahami bahwa proses reduksi data adalah menyederhanakan data agar tidak terlalu meluas atau lebar. Tahapan kedua yaitu penyajian data. Menurut Miles dan Hubermen dalam Muhammad Idrus, penyajian data adalah sekumpulan informasi tersusun yang memberi kemungkinan adanya penarikan kesimpulan. ${ }^{5}$ Karena bersifat kualitatif, maka data penelitian ini disajikan atau dipaparkan penulis dalam bentuk naratif atau berupa kata-kata. Dan tahapan yang ketiga atau terakhir adalah kesimpulan atau verifikasi. Tahapan ini

${ }^{4}$ Sugiyono, Metode Penelitian Kuantitatif dan Kualitatif Dan R \& D, (Ban ung: Alfabeta, 2009), hlm. 338

${ }^{5}$ Muhammad Idrus, Metode Penelitian Ilmu Sosial Pendekatan Kualitatif dan Kuantitatif, (Jakarta: Erlangga, 2009), hlm.151 


\section{Suciati}

merupakan tahapan yang menunjukkan data hasil dari analisis. Dari data kualitatif, jumlahnya sangat banyak sekali. Dalam hal ini, penulis menggunakan metode analisis teks dan bahasa, yang fokus pada content analysis (analisis isi).

\section{B. Pembahasan}

Penanaman nilai pada anak sejak dini sangat penting. Untuk itu, orang tua maupun guru harus mengajarkan nilai-nilai yang positif pada anak maupun anak didik. Penanaman adalah proses, perbuatan dan cara menanamkan. ${ }^{6}$ Sedangkan arti nilai ada beberapa definisi. Menurut Zakiyah Daradjat, nilai adalah suatu perangkat keyakinan atau perasaan yang diyakini sebagai identitas yang memberikan ciri khusus pada pemikiran, perasaan, kriteria maupun perilaku. ${ }^{7}$

Di sisi lain, nilai menurut Sidi Ghazalba adalah suatu yang bersifat abstrak, ideal. Nilai adalah sesuatu yang abstrak, bukan benda konkrit, bukan fakta dan tidak hanya persoalan benar. Namun, nilai memerlukan pembuktian secara empiris melalui penghayatan yang mendalam untuk membedakan apakah itu baik atau tidak dan apakah itu disenangi atau tidak. ${ }^{8}$

Menurut Zubaidi, nilai sosial terdiri atas beberapa sub nilai. Yang pertama yaitu loves (kasih sayang). Sub nilai ini mengandung lima nilai lagi, yaitu pengabdian, tolong menolong, kekeluargaan, kesetiaan dan kepedulian. Kemudian, sub nilai kedua yaitu responsibility (tanggung jawab). Sub nilai ini terdiri atas tiga nilai lagi, yaitu nilai rasa memiliki, disiplin dan empati. Dan sub nilai yang ketiga atau terakhir adalah life harmony (keserasian hidup).

${ }^{6}$ DepDikBud, Kamus Besar Bahasa Indonesia, (Jakarta: Balai Pustaka, 1990), hlm. 895

7 Zakiyah Daradjat, Ilmu Jiwa Agama, (Jakarta: Bulan Bintang, 1996), hlm. 59

8 Chabib Thoha, Kapita Selekta Pendidikan Islam, Yogyakarta: Pustaka Pelajar, 2000), hlm. 60 
Sub nilai yang terakhir ini juga mengandung beberapa nilai, yaitu nilai keadilan, toleransi, kerjasama dan demokrasi. ${ }^{9}$

Menurut Hurlock (1995), perkembangan sosial anak dipengaruhi oleh faktor lingkungan keluarga, faktor lingkungan rumah dan faktor pengaruh pengalaman sosial anak. ${ }^{10}$

\section{Faktor Lingkungan Keluarga}

Lingkungan keluarga adalah lingkungan yang paling dekat dengan anak. Disini, seorang anak belajar bagaimana bersosialisasi dengan orang lain, terutamanya belajar dari orang tua dan saudara. Perkembangan anak sangat terpengaruh oleh bagaimana pola asuh dan bimbingan dari orang tua atau keluarga. Dari keluarga, anak-anak mengenal aspek-aspek dan nilai-nilai kehidupan sosial atau norma kehidupan yang berkembang di lingkungan masyarakat sehari-hari.

Proses bimbingan orang tua ini bisa dinamakan sosialisasi karena orang tua memberikan gambaran dan arahan akan hal-hal yang ada di lingkungan sekitar. Sesuatu yang baru pun diperoleh si anak dari orang tua sehingga dia mengerti dan memahami bagaimana menempatkan diri dalam lingkungan sosial dan bagaimana berinteraksi dengan orang lain.

Perkembangan sosial di keluarga juga dipengaruhi beberapa faktor, yaitu status keluarga, keutuhan keluarga dan sikap serta kebiasaan orang tua. Status keluarga sangat berpengaruh terhadap perkembangan sosial anak. Posisi sebagai kakak, adik, anak dan lainnya tentunya akan mempengaruhi proses sosialisasinya dengan orang lain. Selanjutnya yaitu keutuhan keluarga. Jika sebuah keluarga memiliki keutuhan yang bagus,

${ }^{9}$ Zakiyah Kholidah, Pendidikan Nilai-nilai Sosial bagi Anak dalam K luarga Muslim (Studi Kasus di RT 09 Dukuh Papringan Catur Tunggal Depok Sleman Yogyakarta). AL HIKMAH Jurnal Studi Keislaman, Volume 3, Nomor 1, Maret 2013, hlm. 93-95

${ }^{10}$ Farida, Mayar, Perkembangan Sosial Anak Usia Dini sebagai Bibit u tuk Masa Depan Bangsa, Jurnal Al-Ta'lim, Jilid 1, Nomor 6 November 2013, hlm. 462-563 
maka perkembangan sosial anak pun akan berjalan secara positif karena tidak ada hal-hal yang mengganggu proses sosialisasi tersebut. Dan faktor terakhir yaitu sikap dan kebiasaan orang tua. Anak belajar dari apa yang dia lihat dan apa yang dia dengar. Dengan demikian, sikap dan ucapan yang biasa ditunjukkan oleh orang tua akan ditiru oleh anak-anaknya. Jika orang tua bersikap hangat dan ramah dengan orang lain, maka bisa dikatakan bahwa kemungkinan besar si anak juga akan memiliki sikap tersebut.

\section{Faktor dari Luar Rumah}

Di luar rumah, anak dapat bertemu dengan banyak orang atau banyak pihak, seperti orang tua, orang dewasa, anak kecil, teman sebaya, dan sebagainya dengan usia, jenis kelamin, kematangan dan karakter yang berbeda. Dengan begitu, jangkauan sosialisasinya akan lebih luas dan akan berjalan sesuai dengan peran sosialnya.

\section{Faktor Pengaruh pengalaman Sosial Anak}

Pengalaman sosial anak sangat berpengaruh pada perkembangan sosialnya karena model anak belajar adalah dengan cara mengamati, meniru dan melakukan. Orang dewasa dan teman dekat menjadi objek anak dalam belajar bersosialisasi. Untuk itu, orang dewasa atau siapapun yang ada di lingkungana anak-anak seharusnya memberikan contoh atau model yang pantas karena anak akan menggunakannya sebagai acuan dalam berbicara, bersikap, berpikir, serta bagaimana mengelola kecerdasannya, khususnya kecerdasan sosialnya. Jika anak memiliki pengalaman sosial yang baik, hal ini akan berpengaruh kepada anak bagaimana dia berinteraksi dengan orang lain. Dengan demikian, anak akan tahu bagaimana cara bersosialisasi dengan siapapun di luar rumah.

Adapun untuk nilai sosial, Walter $G$ Everent mengklasifikasikannya menjadi lima bagian, yaitu: 
a. Nilai ekonomi (economic values) yaitu nilai-nilai yang berhubungan dengan sistem ekonomi.

b. Nilai rekreasi (recreation values) yaitu nilai-nilai permainan yang ada pada waktu luang sehingga memberikan kontribusi untuk menyegarkan pikiran, jasmani dan rohani.

c. Nilai perserikatan (association values) yaitu nilai-nilai yang meliputi berbagai bentuk perserikatan, persahabatan maupun hubungan sesama individu atau kelompok.

d. Nilai kejasmanian (body values) yaitu nilai-nilai yang berhubungan dengan kondisi jasmani seseorang.

e. Nilai watak (character values) nilai yang meliputi semua tantangan dan menunjukkan karakter yang meliputi kesalahan pribadi dan sosial termasuk keadilan, kesediaan menolong, kesukaan pada kebenaran, dan kesediaan mengontrol diri.

Selain nilai sosial, nilai agama juga sangat penting untuk ditanamkan kepada anak sejak dini. Nilai ini sebagai dasar anak untuk melakukan apapun. Agama merupakan sesuatu yang berhubungan dengan keimanan. Dalam hal ini adalah agama Islam. Agama ini merupakan perpaduan antara potensi bawaan sejak lahir dan juga pilihan setelah memiliki kesadaran beragama. Hal ini tidak terlepas dari pengaruh luar diri individu. Untuk itu, nilai agama bisa dikatakan sebagai dasar atau prioritas dalam mendidik anak. Agama adalah sesuatu yang dianut seseorang sebagai pegangan hidup untuk mengatur hubungannya dengan tuhan, hubungannya dengan sesama manusia yang lain dan dengan makhluk hidup atau alam yang ada di sekitar. Agama mengatur kesemuanya karena agama mencakup aturan keimanan, peribadatan, norma maupun nilai yang diajarkan oleh Rasulullah dari Allah untuk disampaikan kepada semua umat manusia. 
Menurut Chabib Thoha, penanaman nilai adalah suatu tindakan, perilaku atau proses menanamkan suatu tipe kepercayaan yang berada dalam ruang lingkup sistem kepercayaan dimana seseorang bertindak atau menghindari suatu tindakan,

atau mengenai sesuatu yang pantas atau tidak pantas dikerjakan. ${ }^{11}$ Dari pengertian tersebut, dapat diketahui bahwa penanaman nilai adalah proses mempengaruhi atau mendorong seseorang agar melakukan sesuatu yang positif sesuai dengan aturan dan meninggalkan hal negatif atau sesuatu yang tidak sesuai atau melanggar aturan yang berlaku, baik dari Tuhan ataupun dari masyarakat.

Penanaman nilai ini bisa dilakukan dengan mengaplikasikan pendekatan penanaman nilai, yaitu suatu pendekatan yang memberi penekanan pada nilai-nilai agama dalam diri anak atau siswa. Dalam pendekatan ini, dijelaskan bahwa tujuan pendidikan nilai adalah agar anak atau siswa dapat menerima nilai-nilai agama tertentu dan dapat mengubah dirinya secara individu agar dapat sesuai dengan apa yang diajarkan dalam agama tersebut. Menurut pendekatan penanaman nilai ini, metode yang dapat digunakan untuk proses pembelajaran ada beberapa, misalnya contoh atau keteladanan, penguatan positif dan negatif, simulasi, role play (bermain peran). ${ }^{12}$

Dengan demikian, penulis dapat mengambil kesimpulan bahwa penanaman nilai keagamaan adalah suatu proses usaha yang dilakukan secara sadar, direncanakan dan penuh tanggung jawab dengan tujuan mengarahkan, menjaga dan meningkatkan pengetahuan keagamaan, sikap serta praktek seorang individu dalam hal aqidah, akhlak dan ibadah. Kesemuanya diharapkan dapat diaplikasikan dalam kehidupan sehari-hari secara sadar dan rutin.

11 Chabib Thoha, Kapita Selekta Pendidikan Islam, Yogyakarta: Pustaka Pelajar, 2000), hlm. 61

${ }^{12}$ Masnur Muslich, Pendidikan Karakter, (Jakarta: Bumi Aksara, 2011), hlm. 23 
Bagi seorang anak, perkembangan agama biasanya terjadi ketika dia masih kecil. Hal ini umumnya dialami berdasarkan pengalamannya di lingkungan keluarga, masyarakat dan lingkungan sekolah. Apapun yang dia lihat dan dia dengar, kaitannya dengan agama, akan sangat berpengaruh banyak dalam menentukan kepribadiannya sehingga sikap atau tindakan, ucapan serta kebiasaan kesemuanya akan terpengaruh dan kesemuanya merupakan cerminan dari kualitas pengalaman nilai agamanya. ${ }^{13}$

Keluarga merupakan lingkungan pendidikan yang utama dan pertama bagi anak. Dalam keluarga, anak memperoleh dasardasar agama dan kepribadiannya secara langsung menyesuaikan apa yang ada dalam keluarganya meskipun kebiasaan-kebiasaan yang ada dalam keluarga tersebut tidak dicatat atau ditulis secara eksplisit. Sedangkan, sekolah adalah penerus atau pendukung pendidikan yang ada dalam keluarga. Sekolah memiliki fungsi penguat dalam pendidikan anak. Yang perlu disadari oleh orang tua adalah pendidikan utama dan pertama anak adalah keluarga. Untuk itu, orang tua tidak boleh menuntut sekolah secara berlebihan karena kalau dikalkulasi, jumlah jam anak beradadi rumah lebih banyak daripada jumlah jam anak berada di sekolahan.

Menurut pandangan islam, jenis-jenis nilai agama yang perlu ditanamkan pada anak atau siswa meliputi beberapa nilai.

1. Nilai Keimanan

Iman secara umum dapat dipahami sebagai suatu keyakinan yang dibenarkan didalam hati, diikrarkan dengan lisan, dan dibuktikan dengan amal perbuatan yang didasari niat yang tulus dan ikhlas dan selalu mengikuti petunjuk Allah SW'T serta sunah nabi Muhammad SAW. ${ }^{14}$

13 Zakiyah Daradjat, Ilmu Jiwa Agama, (Jakarta: Bulan Bintang, 2005), hlm. 66

14 Rois Mahfud, Al-Islam Pendidikan Agama Islam, Jakarta: Erlangga, 2011), hlm. 12-13 
2. Nilai Ibadah

Secara bahasa atau etimologi, ibadah adalah merendahkan diri atau tunduk. Sedangkan menurut terminologi atau istilah memiliki makna yang bervariasi. Namun, intinya memiliki makna yang sama, yaitu: ${ }^{15}$

a) Ibadah adalah taat kepada Allah SWT dan menjauhi segala laranganNya

b) Ibadah adalah merendahkan diri kepada Allah SW'T sebagai wujud tunduk atau iman dengan disertai rasa mahabbah (kecintaan) yang paling tinggi.

c) Ibadah adalah meliputi ucapan (lisan), perbuatan maupun apa yang ada di dalam hati. Dengan demikian, ibadah meliputi apa yang dhabir dan yang bathin.

2. Nilai Akhlak

Akblak adalah kata jamak dari kata tunggal khuluq. Khuluq merupakan bentuk batin. Akhlak adalah sesuatu yang telah tercipta atau terbentuk melalui sebuah proses. Karena sudah terbentuk akhlak sering disebut juga dengan istilah kebiasaan. ${ }^{16}$

Untuk mengajarkan dan menanamkan nilai-nilai sosial dan keagamaan di atas, maka orang tua maupun guru hendaknya memiliki alternatif yang tepat untuk anak ataupun siswa. Mediamedia pengajaran ada banyak sekali dan bentuknya sangat variatif. Oleh karena itu, orang tua maupun guru harus memiliki pengetahuan yang cukup tentang media pengajaran. Adapun media pengajaran meliputi banyak hal yang sangat variatif, yaitu sebagai berikut:

a) Media sebagai alat komunikasi guna lebih mengefektifkan proses belajar mengajar;

${ }^{15}$ Yazid bin Abdul Qadir Jawas, Syarah Aqidah Ablus Sunnah Wal Jama'ah, (Semarang: Pustaka Imam asy-Syafi"i, 2004), hlm. 185

${ }^{16}$ Nasirudin, Pendidikan Tasawnf, (Semarang: Rasail Media Group, 2010), hlm. 31 
'Diva The Series' sebagai Media Pembelajaran....

b) Fungsi media dalam rangka mencapai tujuan pendidikan;

c) Seluk-beluk proses belajar;

d) Hubungan antara metode mengajar dan media pendidikan;

e) Nilai atau manfaat media pendidikan dalam pengajaran;

f) Pemilihan dan penggunaan media pendidikan

g) Berbagai jenis alat dan teknik media pendidikan;

h) Media pendidikan dalam setiap mata pelajaran;

i) Usaha inovasi dalam media pendidikan. ${ }^{17}$

Dengan demikian, dapat disimpulkan bahwa media adalah bagian yang sangat penting dan dapat mendukung proses belajar mengajar demi tercapainya tujuan pendidikan pada anak. Kata media berasal dari bahasa Latin medius yang secara harfiah berarti 'tengah', 'perantara' atau 'pengantar'. Dalam bahasa Arab, media berarti perantara atau pengantar pesan dari pengirim kepada penerima pesan. ${ }^{18}$ Dan apabila media tersebut memberikan pesan atau informasi instruksional atau yang memiliki fungsi mendidik atau memberikan pembelajaran kepada si pengguna, maka media tersebut dinamakan media pembelajaran. ${ }^{19}$

Dalam suatu proses pembelajaran atau pendidikan, orang tua dan guru harus tahu bahwa penggunaan media harus disesuaikan dengan kebutuhan dan karakteristik anak. Anakanak dalam masa pengenalan dan memiliki rasa ingin tahu yang besar. Selain itu, mereka juga sangat tertarik dengan hal-hal yang sifatnya menyenangkan atau menghibur. Jadi, dapat disimpulkan bahwa penggunaan media pengajaran dalam proses belajar mengajar dapat menumbuhkan dan meningkatkan keinginan dan minat yang baru, membangkitkan motivasi dan rangsangan

${ }^{17}$ Azhar Arsyad, Media Pengajaran, (Jakarta: Raja Grafindo Persada, 2000), hlm. 2

${ }^{18}$ Ibid, hlm. 3

${ }^{19}$ Ibid, hlm. 4 


\section{Suciati}

kegiatan belajar, dan bahkan membawa pengaruh-pengaruh psikologis terhadap anak atau siswa. Untuk itu, guru dan orang tua harus selektif dan tepat dalam memilih media pembelajaran untuk anak.

Secara umum, manfaat media dalam proses pembelajaran adalah memperlancar interaksi antara guru dengan siswa ataupun orang tua dengan anak sehingga pembelajaran akan lebih efektif dan efisien. Ada beberapa manfaat media dalam pembelajaran. untuk lebih rincinya adalah sebagai berikut:

a) Penyampaian materi pelajaran dapat diseragamkan

b) Proses pembelajaran menjadi lebih jelas dan menarik

c) Proses pembelajaran menjadi lebih interaktif

d) Efisiensi waktu dan tenaga

e) Meningkatkan kualitas hasil belajar siswa atau penerimaan anak

f) Media memungkinkan proses belajar dapat dilakukan dimana saja dan kapan saja sehingga lebih fleksibel dan tidak terpaku pada waktu dan tempat

g) Media dapat menumbuhkan sikap positif anak atau siswa terhadap materi dan proses belajar

h) Mengubah peran guru menjadi lebih positif dan produktif. $^{20}$

Media pembelajaran ada banyak sekali jenisnya, mulai dari yang sederhana sampai yang canggih, yang dibuat secara pribadi sampai yang instan dan tinggal pakai. Anderson mengelompokkan media menjadi 10 jenis, yaitu:

\begin{tabular}{cll}
\hline No & Golongan Media & Contoh dalam Pembelajaran \\
\hline I & Audio & Kaset audio, siaran radio, CD, telepon \\
\hline II & Cetak & Buku pelajaran, modul, brosur, leaflet, gambar \\
\hline III & Audio-cetak & Kaset audio yang dilengkapi bahan tertulis \\
\hline
\end{tabular}

${ }^{20}$ Tim Penyusun, Media Pembelajaran, (Jakarta: Departemen Pendidikan Nasional Direktorat Jenderal Pendidikan Dasar dan Menengah Direktorat Tenaga Kependidikan, 2003), hlm. 17 
'Diva The Series' sebagai Media Pembelajaran....

\begin{tabular}{clll}
\hline IV & $\begin{array}{l}\text { Proyeksi } \\
\text { diam }\end{array}$ & $\begin{array}{l}\text { visual } \\
\text { (slide) }\end{array}$ \\
\hline V & $\begin{array}{l}\text { Proyeksi } \\
\text { visual diam }\end{array}$ & Audio Film bingkai (slide) bersuara \\
\hline VI & Visual gerak & Film bisu \\
\hline VII & $\begin{array}{l}\text { Audio Visual } \\
\text { gerak }\end{array}$ & film gerak bersuara, video/VCD, televisi \\
\hline VIII & Obyek fisik & Benda nyata, model, specimen \\
\hline IX & $\begin{array}{l}\text { Manusia } \\
\text { lingkungan }\end{array}$ & dan & Guru, Pustakawan, Laboran \\
\hline $\mathrm{X}$ & Komputer & CAI (Pembelajaran berbantuan komputer), \\
& & CBI (Pembelajaran berbasis komputer). \\
\hline
\end{tabular}

Dalam penelitian ini, berarti penulis menganalisa media pembelajaran jenis ketujuh, yaitu kartun "Diva The Series" yang ditayangkan di salah satu channel TV swasta, yaitu RTV. Diva The Series merupakan serial televisi untuk anak Indonesia yang diproduksi oleh Kastari Animation (PT.Kastari Sentra Media). Kartun ini berisi tentang gadis kecil bernama Diva yang selalu ditemani oleh kucing putih yang lucu bernama Pupus. Bersama teman temannya dengan latar belakang suku dan agama yang berbeda, Mona, Febi, Putu dan Tomi, banyak konflik seru yang terjadi setiap hari. Ada nilai moral dan pesan positif untuk anakanak Indonesia yang disajikan di setiap episodenya. Melalui serial ini, anak Indonesia diharapkan mendapatkan tontonan kartun anak yang berkualitas dan dproduksi oleh anak bangsa, asli buatan atau produk Indonesia yang menarik dan mendidik.

Berikut adalah episode yang ada dalam Diva The Series episode 1-50 yang menjadi subjek penelitian

\begin{tabular}{ll}
\hline Episode & \multicolumn{1}{c}{ Judul } \\
\hline & Robotku dan Robotmu \\
\hline Tomi Suka Bohong \\
\hline Ada PR dari Bu Guru \\
\hline Bukan Aku \\
\hline Jangan Marah \\
\hline Saat Tomi kehilangan Putu \\
\hline
\end{tabular}


Suciati

\begin{tabular}{l}
\hline \\
\hline Pembalasan Diva \\
\hline Diva Cegukan \\
\hline Nenek Pengemis \\
\hline Temanku sakit \\
\hline Memancing \\
\hline Mona Masih Ngompol \\
\hline Becak Mini \\
\hline Mona Suka Jajan \\
\hline Bermain Angin \\
\hline Bermain Petasan \\
\hline Musim Panas \\
\hline Itu Tidak Sehat \\
\hline Bermain salju \\
\hline Kemping Asik \\
\hline Senyum dan Menyapa \\
\hline Minta Maaf \\
\hline Merusak Tanaman \\
\hline Membuang sampah \\
\hline Ada Dokter Gigi di Sekolah \\
\hline Petak Umpet \\
\hline Baju Batik Mona \\
\hline Ayo Kita Berbagi \\
\hline Bermain Yoyo \\
\hline Mengambil Bola \\
\hline Ingin Seperti Robot \\
\hline Febi Jangan Sedih \\
\hline Mona Sakit Perut \\
\hline Mengantar Kue \\
\hline Rambut keriting Febi \\
\hline Kamarku Kotor \\
\hline Boneka Febi \\
\hline Kupu-kupu \\
\hline Aquarium Tomi \\
\hline Lomba Lari \\
\hline Malon Harapan \\
\hline Kartu Pos Tomi \\
\hline
\end{tabular}


'Diva The Series' sebagai Media Pembelajaran....

\begin{tabular}{l}
\hline Pencuri Misterius \\
\hline Gerhana Bulan \\
\hline Poci Kesayangan Ibu \\
\hline Dicium Singa Laut \\
\hline Guling Diva \\
\hline Bermain Warna \\
\hline Jangan Menaruh Barang Sembarangan \\
\hline
\end{tabular}

Analisis pertama yang dilakukan oleh penulis adalah analisis tentang nilai sosial. Menurut referensi yang dikemukakan Walter $G$ Everent yang telah dibahas di awal, nilai sosial meliputi nilai ekonomi, nilai rekreasi, nilai perserikatan, nilai kejasmanian dan nilai watak. Di antara episode 1-50, penulis menemukan nilai ekonomi yang terkandung, tetapi sangat minim, yaitu dalam episode 50. Nilai rekreasi banyak ditemukan di 50 episode tersebut, diantaranya episode 1, 11, 13, 15, 16, 19, 29, 40 dan 49. Sedangkan nilai kerjasama ada di episode 6, 7, 9, 22, 23, 26, dan 50. Adapun nilai perserikatan yang menunjukkan hubungan atau persahabatan dan nilai watak ada di hampir semua episode tersebut.

Hasil kedua menunjukkan bahwa nilai keagamaan yang terkandung dalam film kartun "Diva the Series" meliputi nilai keimanan, nilai ibadah dan nilai akhlak. Di antara ketiga nilai keagamaan ini, nilai akhlak sangat ditekankan dalam 50 episode ini karena hampir semua episode mengajarkan akhlak yang baik untuk Diva dan kawan-kawannya. Di berbagai episode tersebut, banyak sekali pemain yang melakukan kesalahan, akan tetapi dengan saran dan masukan teman-teman maupun orang tua, akhirnya merekapun menyadari kesalahan dan akhirnya melakukan sesuatu atau berkahlak sesuai dengan apa yang diajarkan dalam agama maupun masyarakat.

Analisis selanjutnya adalah mengenai pengaruh film tersebut terhadap perkembangan anak. Setelah menganalisa secara rinci dan mendalam, tidak dapat dielakkan lagi bahwa film 


\section{Suciati}

"Diva the Series" tersebut dapat memberikan pengaruh positif terhadap perkembangan anak karena nilai yang terkandung di dalamnya sangat positif sekali, baik yang tergolong nilai sosial maupun nilai keagamaan. Anak-anak sifatnya cenderung melihat dan meniru, jadi kartun ini memberikan sajian yang pas dan tepat untuk anak, khususnya secara pribadi dan umumnya secara sosial saat berhubungan dengan lingkungannya masing-masing.

\section{Simpulan}

Berdasarkan pembahasan di poin sebelumnya, dapat disimpulkan bahwa ada beberapa nilai sosial dan nilai keagamaan yang terkandung dalam kartun "Diva the Series". Hasil pertama menunjukkan bahwa nilai sosial yang terkandung dalam film tersebut meliputi nilai rekreasi, nilai perserikatan, nilai kejasmanian dan nilai watak. Di antara ke empat nilai sosial tersebut, nilai watak dan nilai perserikatan sangat ditekankan dalam film ini sehingga mendominasi dari nilai lainnya. Hasil kedua menunjukkan bahwa nilai keagamaan yang terkandung dalam film kartun "Diva the Series" meliputi nilai keimanan, nilai ibadah dan nilai akhlak. Penyampaian nilai keagamaan ini sangat difokuskan pada nilai akhlak. Dan hasil ketiga menunjukkah bahwa film kartun "Diva the Series" memiliki pengaruh positif terhadap perkembangan anak karena mengandung nilai sosial dan keagamaan yang sangat tinggi sehingga anak menjadi lebih sensitif dan responsif terhadap kondisi apapun karena terbiasa disajikan nilai-nilai yang sarat makna. 


\section{Daftar Pustaka}

Arsyad, Azhar, Media Pengajaran, Jakarta: Raja Grafindo Persada, 2000

Daradjat, Zakiyah, Ilmu Jiwa Agama, Jakarta: Bulan Bintang, 2005

Daradjat, Zakiyah, Ilmu Jiwa Agama, Jakarta: Bulan Bintang, 1996 DepDikBud, Kamus Besar Bahasa Indonesia, Jakarta: Balai Pustaka, 1990

Dey, Ian, Qualitative Data Analysis, New York: RNY, 1995

Jawas, Yazid bin Abdul Qadir, Syarah Aqidah Ablus Sunnah Wal Jama'ah, Semarang: Pustaka Imam asy-Syafi"i, 2004

Kholidah, Zakiyah. Pendidikan Nilai-nilai Sosial bagi Anak dalam Keluarga Muslim (Studi Kasus di RT 09 Dukuh Papringan Catur Tunggal Depok Sleman Yogyakarta). AL HIKMAH Jurnal Studi Keislaman, Volume 3, Nomor 1, Maret 2013

Mahfud, Rois, Al-Islam Pendidikan Agama Islam, Jakarta: Erlangga, 2011

Mayar, Farida, Perkembangan Sosial Anak Usia Dini sebagai Bibit untuk Masa Depan Bangsa, Jurnal Al-Ta'lim, Jilid 1, Nomor 6 November 2013

Moleong, Lexy J, Metodologi Penelitian Kualitatif, Bandung: PT. Remaja Rosdakarya, 2009

Muhammad Idrus, Metode Penelitian Ilmu Sosial Pendekatan Kualitatif dan Kuantitatif, Jakarta: Erlangga, 2009

Muslich, Masnur, Pendidikan Karakter, Jakarta: Bumi Aksara, 2011 
Suciati

Nasirudin, Pendidikan Tasawnf, Semarang: Rasail Media Group, 2010

Pendidikan Dasar dan Menengah Direktorat Tenaga Kependidikan, 2003

Sugiyono, Metode Penelitian Kuantitatif dan Kualitatif Dan R \& D, Bandung: Alfabeta, 2009

Thoha, Chabib, Kapita Selekta Pendidikan Islam, Yogyakarta: Pustaka Pelajar, 2000

Tim Penyusun, Media Pembelajaran, Jakarta: Departemen Pendidikan Nasional Direktorat Jenderal

Zubaidi, Pendidikan Berbasis Masyarakat, Yogyakarta: Pustaka Pelajar, 2006 